\title{
RAPSODYK NA AMBONIE? \\ JAN PAWEŁ II NA PLACU ZWYCIĘSTWA W WARSZAWIE W ŚWIETLE ZAŁOŻEŃ TEATRU RAPSODYCZNEGO MIECZYSŁAWA KOTLARCZYKA
}

Powszechnie wiadomo, że jedną z ważniejszych osób w biografii Karola Wojtyły był Mieczysław Kotlarczyk, nauczyciel prywatnego gimnazjum w Wadowicach, założyciel Amatorskiego Teatru Powszechnego w tym mieście, a później twórca Teatru Rapsodycznego w Krakowie. Miał on bardzo duży wpływ na kształtowanie osobowości artystycznej przyszłego papieża, i to już od czasów, gdy młody Wojtyła grał Kirkora w reżyserowanej przez niego w Wadowicach Balladynie. To właśnie Mieczysław Kotlarczyk wprowadził ambitnego ucznia w świat wielkiej literatury romantycznej i młodopolskiej, rozmawiał z nim godzinami na tematy literackie i teatralne. Ta znajomość, która z czasem przekształciła się w przyjaźń, była kontynuowana później w Krakowie. Wojtyła był jednym z głównych aktorów w tworzonym w latach okupacji teatrze Kotlarczyka. Jak to ujął Jacek Popiel: ,Trudno [...] wyobrazić sobie biografię Wojtyły bez studiów polonistycznych, tajnego Teatru Rapsodycznego, przyjaźni z Mieczysławem Kotlarczykiem i bez rodzących się

Mgr Magdalena JANKosZ - doktorantka, Wydział Nauk Społecznych Uniwersytetu Papieskiego Jana Pawła II w Krakowie; adres do korespondencji: ul. Kanonicza 9/301, 31-002 Kraków; e-mail:jankosz.magdalena@gmail.com. ORCID: http://orcid.org/0000-0002-8249-9612.

Ks. prof. dr hab. WiesŁaw Przyczyna - Wydział Teologiczny UPJP II w Krakowie; Katedra Stylistyki i Lingwistyki Antropologicznej na Wydziale Filologicznym Uniwersytetu w Białymstoku; kierownik projektu badawczego „Słownik polskiej terminologii prawosławnej”; członek Rady Języka Polskiego przy Prezydium PAN; adres do korespondencji: Uniwersytet Papieski Jana Pawła II, ul. Kanonicza 9/305, 31-002 Kraków; e-mail: wieslaw.przyczyna@upjp2.edu.pl. ORCID: http://orcid. org/0000-0001-8445-0401. 
w Krakowie przemyśleń, w których świat sztuki łączył się ze światem ducha, a świat ducha ze światem sztuki”" (Los artysty w czasach zniewolenia 287).

Po podjęciu decyzji o zostaniu kapłanem Wojtyła stopniowo rezygnował jednak z czynnej działalności w Teatrze Rapsodycznym, po kilku miesiącach formacji seminaryjnej przestał odgrywać role teatralne. Zasadne jest w tym miejscu postawienie kilku pytań: Jak ten okres jego życia zaważył na późniejszej działalności kaznodziejskiej? Które z założeń Teatru Rapsodycznego były w tej działalności najbardziej obecne? Czy można powiedzieć, że był on rapsodykiem na ambonie, a jeśli tak, to w jakim zakresie? Aby odpowiedzieć na te pytania, opiszemy najpierw założenia ideowe Teatru Rapsodycznego w ujęciu Kotlarczyka. Następnie przedstawimy zarejestrowane na wideo wystąpienie Jana Pawła II podczas homilii ${ }^{1}$ na pl. Zwycięstwa w Warszawie 2 czerwca 1979 roku² $^{2}$. W ostatniej części przeanalizujemy to wystąpienie w świetle założeń Teatru Rapsodycznego i podamy wynikające z tego wnioski.

\section{ZAŁOŻENIA IDEOWE I ARTYSTYCZNE TEATRU RAPSODYCZNEGO MIECZYSŁAWA KOTLARCZYKA}

Teatr według Mieczysława Kotlarczyka miał do spełnienia bardzo ważną funkcję, powinien być „drogą do doskonałości” i sposobem przekazywania prawdy o życiu (Dziedzic 79). Dlatego przed aktorem takiego teatru stawiane były bardzo wysokie wymagania zarówno pod względem warsztatu, jak i rozwoju intelektualnego oraz etycznego. Kotlarczyk oczekiwał od niego pogłębionej wiedzy z zakresu różnych dziedzin humanistyki, starannego wykształcenia, ale także szlachetnego charakteru. Powinien to być człowiek wartościowy, postępujący etycznie. Jak to trafnie ujął Stanisław Dziedzic: „Kotlarczyk pojmował funkcję aktora jako swoiste kapłaństwo, otwierające drogę do królestwa transcendentnej prawdy" (79). Aktor, nadrzędna osoba w teatrze, nie mógł jednocześnie być aktorem solistą. Miał on być głosem w chórze, który wpływa na całościowy kształt przedstawienia. W teatrze żywego słowa ograniczona została tzw. gra, przeżywanie, dążenie do realizmu i prawdy scenicznej. Aktor miał wyjść poza tekst, stanąć obok kreowanej postaci, nie próbować

\footnotetext{
${ }^{1}$ Od Soboru Watykańskiego II jednostkę przepowiadania, która występuje w celebracji eucharystycznej po ewangelii, nazywa się homilią, a nie kazaniem.

${ }^{2}$ Wybraliśmy to wystąpienie jako materiał źródłowy po pierwsze dlatego, że jest jednym z najbardziej znanych, że podkreśla się jego wpływ na przemiany społeczne i polityczne w Polsce po 1979 roku, a także z tego względu, że Papież był wówczas młody, zdrowy, w pełni sił, dzięki czemu mógł wykorzystywać wszystkie swoje fizyczne predyspozycje, co w późniejszych latach ze względu na wiek i ograniczenia związane z chorobą nie było już możliwe.
} 
nią się stać. Jak stwierdził Wojtyła: „aktor rapsodyczny nie staje się daną postacią, ale niesie pewien problem" (cyt. za: Popiel, Los artysty w czasach zniewolenia 234). Specyficzną rolę aktorów podkreślał również fakt, że na afiszach teatralnych Teatru Rapsodycznego nie umieszczano ich nazwisk, a po zakończonym spektaklu nie wychodzili oni do ukłonów. Ważne było również, aby aktorzy rapsodyczni znali realia świata, w którym funkcjonowali. „Nowoczesny artysta żywego słowa powinien być - podkreśla Kotlarczyk - czułym słuchaczem nie tylko autora i samego siebie, ale i społeczeństwa, z którego wyrasta i w którym żyje" (cyt. za: Popiel, Los artysty w czasach zniewolenia 235).

Teksty wybierane do realizacji przez rapsodyków nie zawsze były dramatami. Szczególne było tu odkrycie, że myśl i sam proces myślenia ma wymiar dramatyczny. Pozwoliło ono na sięganie po utwory poetyckie czy powieściowe (bardzo często były to dzieła romantyków). Według Kotlarczyka ważniejszy był problem, idea niż akcja sceniczna, dlatego właśnie utwory niesceniczne mogły się stać podstawowym materiałem teatralnym. Pisał o tym zresztą Wojtyła w recenzji O teatrze słowa (Popiel, Los artysty w czasach zniewolenia 289).

Najważniejsze w tym teatrze było jednak słowo, ono stawało się właściwym tworzywem teatralnym. „Teatr Rapsodyczny narodził się z zachwytu nad słowem” (Popiel, Los artysty w czasach zniewolenia 187). Mieczysław Kotlarczyk często powtarzał za Adamem Mickiewiczem, że „prawdziwe słowo, którego cudowne właściwości wymieniliśmy, każde prawdziwe słowo jest promieniem Słowa Bożego" (cyt. za: Kotlarczyk 275). Być może dlatego „Słowo” w tekstach programowych czy w listach zapisywane było wielką literą, co podkreśla jego boskie pochodzenie ${ }^{3}$.

Porywała go [Kotlarczyka - M.J., W.P.] potęga słowa, nie tylko w zakresie przekazywania idei, ale także wydobywania emocji. Mowę w takim rozumieniu ożywiała bliskość pomiędzy mówiącym i słuchającym. Aktor służyć miał kreacji „teatru słowa wewnętrznego”. [...] Jego teatr miał uobecniać uniwersalne prawdy i wartości moralne, a nadrzędna w nim rola słowa miała otwierać drogę do doskonałości. (Dziedzic 79)

Aby rola słowa była należycie uwydatniona, należało je odpowiednio wypowiadać. Wydaje się, że właściwym określeniem dla wypowiadania słów w teatrze Kotlarczyka jest nie tyle odgrywanie, deklamowanie czy recytowanie (chociaż wszystkie te

\footnotetext{
${ }^{3}$ Osoby z kręgu Mieczysława Kotlarczyka często zapisywały rzeczownik ,słowo” wielką literą, aby podkreślić jego znaczenie. W cytatach zachowana została pisownia zgodna z oryginałem. W tekście autorzy w odniesieniu do słowa w kontekście literackim zapisują je małą literą, podobnie gdy wspominają o słowie Bożym biblijnym, a wielką - Słowo Boże - gdy mają na myśli Chrystusa (zgodnie $\mathrm{z}$ zasadami pisowni słownictwa religijnego).
} 
określenia funkcjonowały w odniesieniu do Teatru Rapsodycznego), ile mówienie artystyczne.

Mówienie artystyczne, piękne, wymaga na pewno czegoś więcej niż codzienne mówienie o życiu. Takie artystyczne żywe słowo, niezwykłe, różni się od słowa zwykłego w sposób zasadniczy, bo o całą dziedzinę własnej techniki, artyzmu i kultury. Warunkiem kunsztu żywego słowa jest przede wszystkim głos dobrze postawiony, czyli szkolony i wyszkolony dla celów artystycznych. Kunszt ten zakłada następnie nienaganną dykcję, czyli wymowę, oraz umiejętne operowanie zespołem najrozmaitszych środków wyrazu, takich jak: tempo, rytm, dynamika, intonacja, barwa, modulacja, precyzja słowa i zdania, frazowanie czy pauza artystyczna. (Kotlarczyk 22)

Bardzo ważną rolę Kotlarczyk przypisywał pracy nad szkoleniem głosu. W jego Sztuce żywego słowa odnaleźć można wiele wskazówek dotyczących m.in. wyrazistości głosu, jego barwy, siły. Zwracał uwagę na prawidłową wymowę, na funkcję oddechu, na akcentowanie. Pisząc o takich elementach jak tempo wypowiedzi czy jej rytm, podkreślał, że muszą one być stosowane w sposób przemyślany, że artysta powinien za każdym razem odpowiadać sobie na pytanie, dlaczego używa takiego, a nie innego tempa czy rytmu, dlaczego posługuje się daną modulacją, intonacją, dynamiką, dlaczego frazuje w określony sposób i dlaczego operuje wybraną przez siebie pauzą artystyczną (por. Kotlarczyk 259-260). Według niego nadrzędną zasadą przy doborze różnych środków wyrazu powinna być „,zasada nowoczesnej ekonomii, zasada zdyscyplinowanego, oszczędnego i powściągliwego posługiwania się tymi środkami. Obowiązuje zasada maksymalnego wyrazu przy użyciu minimalnych środków" (Kotlarczyk 259).

Kotlarczyk kładł bardzo duży nacisk na zasady recytacji i sztuki wymowy. Aktorzy jego teatru osiągnęli pod tym względem najwyższy poziom, doceniany nawet przez krytyków nieprzychylnie nastawionych do idei teatru żywego słowa. Do doskonałości doprowadził sztukę recytacji zbiorowej, chóralnej. Niezwykle ważna była też dla niego interpretacja tekstu, zwłaszcza wiersza.

Do końca życia wierzył, że piękne podanie tekstu, szczególnie tekstu napisanego „mową wiązaną", powinno być marzeniem i obowiązkiem artysty teatru. Mistrzostwo słowa, uwidaczniające się m.in. w umiejętności pełnego wykorzystania formalnych struktur wiersza, decyduje o pięknie i prawdziwości teatru, umożliwia najpełniejsze odczytanie idei utworu. (Popiel, Los artysty w czasach zniewolenia 232)

Przypisując nadrzędną rolę słowu, Kotlarczyk nie pomija zupełnie gestu w swoich rozważaniach teoretycznych oraz w pracy z aktorem. Twierdzi, że: „Sztuka deklamacji i recytacji wzmaga swój artystyczny wyraz, osiąga pełnię swojej ekspresji poprzez artystyczny i pełen ekspresji ruch i gest" (Kotlarczyk 306). Aby wyjaśnić, jak powinien wyglądać gest w teatrze żywego słowa, posługuje się terminem Rudolfa Steinera: „eurytmia”. Polega ona na muzycznym rytmizowaniu mowy z ruchem, 
harmonii mowy z gestem. „Plastyczna, widoma, widzialna wizualna mowa. Widzialność słowa. Ożywiona ruchem, gestem mowa trzech planów: fizycznego, psychicznego i duchowego" (Kotlarczyk 306). Gest w Teatrze Rapsodycznym w praktyce scenicznej był bardzo oszczędny, aktor postrzegany był jako statyczny, nawet ruch głową należał do rzadkości ${ }^{4}$. Ruch sceniczny zastąpiony został niejako ruchem myśli. Wojtyła w jednym ze swoich listów do Kotlarczyka pisał:

Człowiek, zarówno aktor, jak i widz-słuchacz, uwalnia się w ten sposób od natrętnej przesady gestu, od aktywizmu, który wewnętrzną duchową istotę człowieka raczej przytłacza, niż rozbudowuje, a chwyta te proporcje, których na co dzień nie może uchwycić i osiągnąć. Przez to udział w przedstawieniu teatralnym mimo woli staje się dlań czymś odświętnym, odbudowuje bowiem w nim samym proporcje pomiędzy myślą i gestem, do których człowiek przynajmniej podświadomie czasem tęskni. Na tym też polega poniekąd owa rola katartyczna, rola pewnego oczyszczenia psychologicznego, którą teatr może spełnić. (Cyt. za: Popiel, „Krytyk teatralny” 140-141)

Postawa aktora rapsodycznego to na ogół postawa stojąca, wyprostowana. Jego mimika - tak jak gest - była raczej oszczędna. Kostium rapsodyczny, podobnie jak elementy scenografii, nie mógł zwracać szczególnej uwagi, odciągać jej od słowa. Był bardzo skromny. Zazwyczaj składały się na niego takie elementy: ciemna, suto marszczona spódnica i biała, płócienna bluzka dla pań, czarne spodnie, biała koszula i szara peleryna dla panów. Dekoracje również były ograniczone do minimum.

\section{JAN PAWEŁ II NA PLACU ZWYCIĘSTWA W WARSZAWIE5}

2 czerwca 1979 roku na placu Zwycięstwa przemawiał do zgromadzonego thumu Jan Paweł II, głowa Kościoła katolickiego, zwierzchnik Państwa Watykańskiego; do niedawna zastępca przewodniczącego Konferencji Episkopatu Polski, metropolita krakowski, wykładowca etyki na Katolickim Uniwersytecie Lubelskim; autor m.in. takich monografii, jak Mitość i odpowiedzialność (1960), Osoba i czyn (1969).

Tekst, który Jan Paweł II postanowił wygłosić jako inaugurujący jego pielgrzymkę, miał staranną kompozycję. Został napisany piękną polszczyzną, są w nim odwołania do poezji Artura Oppmana, do historii, do wielkiej tradycji narodu, do ważnych

\footnotetext{
${ }^{4}$ Deklamator - bo taką rolę odgrywał często aktor w Teatrze Rapsodycznym - „w przeciwieństwie do recytatora - mógł wykorzystywać gest (aż do połowy XX wieku recytator nie mógł używać pozawerbalnych środków wyrazu). Obecnie, choć pozasłowie jest formalnie dopuszczane, to jednak na konkursach sztuki żywego słowa recytatorzy zdecydowanie częściej opierają się na samym słowie" (Flader-Rzeszowska, „Sztuka żywego słowa”).

${ }^{5}$ Ze względu na problem badawczy postawiony w tym artykule interesuje nas nie tyle treść i idee homilii Jana Pawła II, ile sposób ich przekazywania.
} 
postaci. Przywołując myśl Wacława Oszajcy, można się tu też dopatrzyć struktury hymnu ${ }^{6}$. Do hymnu zbliża homilię Jana Pawła II zarówno uroczysty i podniosły charakter, liczne apostrofy, jak i tematyka religijna i patriotyczna oraz dopowiedzenia i rozwinięcia treści budujących dramaturgię. Na uwagę zasługuje również muzyczne rytmizowanie omawianego tekstu, uzyskiwane m.in. przez powtarzanie tych samych słów na początku wersów, np.

To wszystko w rękach Bogarodzicy - pod krzyżem na Kalwarii i w wieczerniku Zielonych Świąt.

To wszystko: dzieje Ojczyzny, tworzone przez każdego jej syna i każdą córkę od tysiąca lat i w tym pokoleniu, i w przyszłych - choćby to był człowiek bezimienny i nieznany, tak jak ten żołnierz, przy którego grobie stoimy...

To wszystko: i dzieje ludów, które żyły wraz z nami i wśród nas, jak choćby ci, których setki tysięcy zginęły w murach warszawskiego getta.

To wszystko w tej Eucharystii ogarniam myślą i sercem i włączam w tę jedną jedyną Najświętszą Ofiarę Chrystusa na placu Zwycięstwa. (Jan Paweł II 25) ${ }^{7}$

Pierwszy Papież, jaki odwiedził Polskę, w dodatku Papież z Polski pochodzący, chciał przekazać swoim rodakom ważne słowa, wiedział, że wszyscy na te słowa czekają. Wśród nich najważniejsze były słowa Pisma Świętego zawarte w lekcjonarzu i komentowane w homilii. Według Soboru Watykańskiego II słowa Pisma Świętego zawierają słowo Boże i są słowem Bożym (por. Sobór Watykański II 557). Oznacza to, że na placu Zwycięstwa w Warszawie 2 czerwca 1979 roku w czytanych tekstach biblijnych i głoszonej homilii rozbrzmiewało słowo Boga skierowane do konkretnego człowieka, z jego pytaniami i problemami (Przyczyna 57-63).

Aby przekazywane przez Papieża słowa należycie wybrzmiały, wykorzystał on wszystkie elementy swojego warsztatu mówcy. Zwraca uwagę jego głos: mocny, silny, dobrze postawiony, o przyjemnej barwie, wyraźnie szkolony. Są momenty, w których ten głos się podnosi, dominuje jednak ton spokojny, wyważony, momentami niemal

${ }^{6}$ „Taką podstawową strukturą, wokół której papież buduje swoje kazania, jest hymn. Nie występuje on jednak w formie czystej, ale jest jakby kręgosłupem, osnową, rusztowaniem, na którym rozpięte jest kazanie. Jego poszczególne wersy mogą stanowić np. początek nowego wątku treściowego czy też początek dalszego rozwinięcia treści. W ten sposób przez dopowiedzenia wyjaśniające, rozwijające i konkretyzujące treść poszczególnych wersetów, hymn-osnowa zostaje rozbudowany i przekształcony w utwór w swojej formie najbliższy poematowi prozą" (Oszajca 27-28).

7 „Nie lekceważąc doniosłości treściowej tego orędzia papieskiego do Polaków wygłoszonego 2 czerwca 1979 roku, ośmieliłbym się utrzymywać, że było ono bardziej dziełem artystycznym, dającym do myślenia, napisanym na głos ludzki i jednego wykonawcę, niż dziełem ściśle intelektualnym: teologicznym, historiozoficznym, historycznym. Ojciec Święty objawił się zatem rodakom na placu Zwycięstwa w Warszawie bardziej jako papież - duszpasterz i artysta niż jako papież - duszpasterz i intelektualista" (Sokół 179). 
konfesyjny. Dość często i umiejętnie Jan Paweł II stosuje frazowanie, a także pauzy, którą można nazwać pauzami artystycznymi. Panuje nad ich długością. Wiele razy te pauzy wypełniane były oklaskami uczestników liturgii, trwającymi niekiedy nawet kilka minut, jak również spontanicznym śpiewem. Zadając pytania, których w tekście jest stosunkowo dużo (są to pytania retoryczne), mówca niekiedy ścisza głos, jakby chciał zachęcić do refleksji. Analizując fragment homilii, w którym Papież mówi:

Czyż przeto nawiązując do tych Chrystusowych słów, nie wolno nam wnosić zarazem, że Polska stała się w naszych czasach ziemią szczególnie odpowiedzialnego świadectwa? Że właśnie stąd - z Warszawy, a także z Gniezna, z Jasnej Góry, z Krakowa, z całego tego historycznego szlaku, który tyle razy nawiedzałem w swoim życiu i który w tych dniach znów będę miał szczęście nawiedzić, że właśnie stąd ze szczególną pokorą, ale i ze szczególnym przekonaniem trzeba głosić Chrystusa? Że właśnie tu, na tej ziemi, na tym szlaku, trzeba stanąć, aby odczytać świadectwo Jego Krzyża i Jego Zmartwychwstania? Ale, umiłowani rodacy - jeśli przyjąć to wszystko, co w tej chwili ośmieliłem się wypowiedzieć - jakżeż ogromne z tego rodzą się zadania i zobowiązania! Czy do nich naprawdę dorastamy? (Jan Paweł II 21)

- można zauważyć, że pauzy po trzech pierwszych pytaniach wypełnione są oklaskami. Ostatnie pytanie, skłaniające do osobistej refleksji i swoistego rachunku sumienia, zostało zadane ściszonym tonem, dlatego po nim oklaski się nie rozległy.

Jan Paweł II, wygłaszając homilię, wykonuje - jak każdy mówca - różne gesty. Trzeba jednak podkreślić, że jak na dość długą homilię, trwającą około 50 minut, było ich stosunkowo niewiele. Miało to z pewnością związek również z sytuacją komunikacyjną liturgii, która ogranicza homilistę pod tym względem (por. Jankosz, „Sytuacje komunikacyjne publicznych wystąpień Jana Pawła II”). Ponadto, Jan Paweł II odczytywał przygotowany wcześniej tekst, a badania wskazują, że najwięcej gestów towarzyszy mowie spontanicznej. Trzeba też zwrócić uwagę na jeszcze jeden szczegół: najważniejszym, końcowym słowom tej homilii nie towarzyszył żaden gest. Przywołany i sparafrazowany przez Papieża cytat z psalmu:

\section{Niech zstąpi Duch Twój! \\ Niech zstąpi Duch Twój! \\ I odnowi oblicze ziemi.}

Tej Ziemi! (25)

wypowiedziany został bez podkreślenia gestem. Tu objawiła się moc Słowa Bożego, w stosunku do którego Papież mógł przyjąć tylko jedną postawę: pokory8. Wyraźny gest pojawia się wcześniej, przy słowach:

\footnotetext{
${ }^{8}$ Bardzo trafnie moc tych słów ujął D. Kosiński: „w sposób najbardziej dosłowny stały się one ciałem” („Performer. Jan Paweł II”).
} 
I wołam, ja, syn polskiej ziemi, a zarazem ja: Jan Paweł II papież, wołam z całej głębi tego tysiąclecia, wołam w przeddzień święta Zesłania, wołam wraz z wami wszystkimi [...]. (25)

To są słowa Jana Pawła II. One potrzebują wzmocnienia, podkreślenia ich treści. Słowa psalmisty, podkreślone powtórzeniem i dodaniem zaimka wskazującego, nie wymagają już żadnych dodatkowych środków wyrazu.

Na uwagę zasługuje także postawa i wyraz twarzy Jana Pawła II. Papież stoi, jest dostojny, wyprostowany. Powagi dodają mu szaty liturgiczne i papieska mitra. Jego mimika jest bardzo stonowana. To ten sam Papież, który kilka godzin wcześniej promiennie uśmiechnięty pozdrawiał wiwatujące tłumy. Podczas homilii jest skupiony, poważny, zamyślony, bardzo rzadko delikatnie się uśmiecha. Nawet wtedy, kiedy tłum wiwatuje, bije brawo przez dłuższy czas, śpiewa, ekspresja jego twarzy jest oszczędna.

\section{WYSTĄPIENIE JANA PAWŁA II NA PLACU ZWYCIĘSTWA A ZAŁOŻENIA TEATRU RAPSODYCZNEGO}

Zestawienie wystąpienia Jana Pawła II z cechami, jakimi według Kotlarczyka musiał odznaczać się rapsodyk, pokazuje podobieństwa zachodzące między nimi. Dotyczą one wszystkich istotnych elementów związanych z posługiwaniem się słowem. Aktor Teatru Rapsodycznego powinien wyróżniać się wykształceniem humanistycznym i dobrze ukształtowanym charakterem, a także znajomością realiów życia odbiorcy, do którego się zwraca. Znajomość biografii Jana Pawła II pozwala stwierdzić, że spełniał on wszystkie te warunki: jego postać postrzegana była bardzo pozytywnie, odebrał staranne wykształcenie filozoficzne i teologiczne, cechowała go wrażliwość artystyczna i umiejętność nawiązywania bliskiej relacji z wiernymi. Dobrze znał sytuację społeczną i polityczną swojej ojczyzny, pomimo że od prawie roku mieszkał w Watykanie. Wiedział, z jakimi problemami zmagają się jego rodacy.

W Teatrze Rapsodycznym tekst będący przedmiotem interpretacji aktorskiej nie musiał być dramatem, rapsodycy chętnie sięgali po prozę i poezję, a jednym z ich ulubionych gatunków był hymn. Dramatyzm wypowiedzi rapsodycznej tkwił nie $\mathrm{w}$ formie tekstu, ale $\mathrm{w}$ procesie myślenia, przedstawionym problemie. Tak też ma się rzecz z homilią Jana Pawła II przybierającą w niektórych fragmentach formę hymnu. Jej tekst jest silnie udramatyzowany, ale nie w warstwie formalnej, tylko przesłania. Ten dramatyzm widać na przykład w opisaniu losów człowieka na tle ważnych wydarzeń historycznych, na zaprezentowaniu jego zmagań, codziennej walki z samym sobą i światem zewnętrznym. Dramatyczny charakter homilii uwidacznia się także w prezentowaniu różnych napięć tkwiących w naturze ludzkiej. Przykładem obrazowania takiego rozdarcia mogą być słowa: 
Człowieka bowiem nie można do końca zrozumieć bez Chrystusa. A raczej: człowiek nie może siebie sam do końca zrozumieć bez Chrystusa. Nie może zrozumieć, ani kim jest, ani jaka jest jego właściwa godność, ani jakie jest jego powołanie i ostateczne przeznaczenie. Nie można tego wszystkiego zrozumieć bez Chrystusa. (22-23)

Dla rapsodyków najważniejsze było zawsze słowo. Służyło im ono do przekazywania idei, wyrażania emocji i uczuć, kształtowania zachowań i postaw oraz przekraczania transcendencji. Słowo było też ważne dla Jana Pawła II. Najważniejsze jednak dla niego było słowo Boże. Jako teolog wiedział, że stanowi ono podstawę kościelnego nauczania w myśl Soboru Watykańskiego II: „Tym słowem Pisma św. żywi się [...] i rozwija posługa słowa, czyli kaznodziejstwo, katecheza i wszelkie nauczanie chrześcijańskie" (Sobór Watykański II 557).

Z wyjątkową rolą słowa w Teatrze Rapsodycznym wiązał się sposób jego wypowiadania, nazwany przez Kotlarczyka „mówieniem artystycznym”. Charakteryzowało się ono dobrze ustawionym głosem, nienaganną dykcją, świadomym posługiwaniem się takimi środkami wyrazu jak: wysokość głosu, tempo, intonacja, frazowanie i pauza. Jan Paweł II, wygłaszając homilię na placu Zwycięstwa, również posługiwał się w kilku fragmentach takim sposobem mówienia. Nie była to recytacja, nie była to także deklamacja. Daleko też sposobowi wypowiadania tekstu przez Jana Pawła II do tak zwanego stylu kaznodziejskiego wyróżniającego się patosem. Jeśli pojawiał się patos jako kategoria estetyczna, to raczej na poziomie słów, a nie ich mówienia. Biorąc pod uwagę aspekty paralingwistyczne tej homilii, należy też zwrócić uwagę na naturalność, dynamikę i empatię parajęzykową, intonację modulowaną w zależności od treści, zmienne tempo, wykorzystanie logicznych pauz oraz spontaniczny poziom natężenia głosu. Wiesław Przyczyna i Aneta Załazińska taki sposób mówienia nazywają stylem partnerskim (Przyczyna i Załazińska 134).

W Teatrze Rapsodycznym elementami, które pozwalały wyeksponować słowo, były gesty. Według Kotlarczyka miały one wspierać słowo i czynić je widzialnym. Nie mogło ich jednak być zbyt wiele, aby nie przesłaniać tego słowa. Podobnie wygląda gestykulacja Jana Pawła II na placu Zwycięstwa. Papież posługiwał się również gestami, choć robił to w sposób bardzo oszczędny. Większość z nich to batuty. Wiążą się one z akcentami i rytmem wypowiedzi, ponadto pomagają logicznie posegmentować tekst, ale przede wszystkim pełnią funkcję semantyczną - pokazują, które fragmenty tekstu są dla odbiorcy najważniejsze i jaki jest jego stosunek emocjonalny do wypowiadanych treści. Zauważyć trzeba w tym miejscu, że im bardziej

\footnotetext{
${ }^{9} \mathrm{~W}$ homilii wygłoszonej na placu Zwycięstwa można odnaleźć też elementy stylu autorytarnego, niektóre fragmenty wypowiadane są tonem doniosłym i patetycznym. Biorąc jednak pod uwagę, o jak ważnych rzeczach mówił wówczas Papież, w jakim miejscu, jaka była waga tamtego wydarzenia, styl ten miał prawo się pojawić.
} 
perswazyjny jest charakter tekstu, tym częstsze i mocniejsze są wykonywane przez mówcę ruchy batutowe. I rzeczywiście, najbardziej perswazyjnym fragmentom homilii Jana Pawła II towarzyszą gesty batutowe. Wykonywał je albo jedną ręką, albo potrząsał obiema rękami i trzymanymi w nich kartkami. Otwierał również kilka razy szeroko ręce, tak jakby chciał objąć nimi wszystkich, podnosił je do góry, kierując myśli i oczy swoich słuchaczy ku niebu. Jednocześnie podkreślał swoją postawę otwartą na wszystkich i chęć ogarnięcia swoich rodaków (por. Jankosz, „Rola gestów narracyjnych w publicznych wystąpieniach Jana Pawła II").

Kolejnym elementem odgrywającym ważną rolę w Teatrze Rapsodycznym była postawa. Aktor u Mieczysława Kotlarczyka na ogół stoi, taka postawa sprzyja odpowiedniej pracy narządu mowy. W tradycji Kościoła przyjęło się, że Papież, zgodnie z ceremoniałem biskupim obowiązującym do 1984 roku, wygłaszał homilię na siedząco (podobnie czynili biskupi). Jan Paweł II nie skorzystał z tego przywileju, głosił homilię stojąc. Był wyprostowany, wyglądał majestatycznie, dostojnie. Postawa stojąca podkreślała znaczenie wypowiadanych przez niego słów. Jego mimika jest oszczędna i wyważona, nie ujawnia zbyt wiele emocji swoją twarzą. Podobnie jak to było w przypadku gestykulacji, można się w tym dopatrywać wpływu sytuacji komunikacyjnej i wymogów liturgii, ale w spokoju i powadze bijącej z twarzy Jana Pawła II widać też wielką odpowiedzialność za słowo i świadomość, że tak właśnie należy je przekazywać ${ }^{10}$.

Wszystkie zachowania Jana Pawła II towarzyszące homilii wygłoszonej na placu Zwycięstwa, sposób jej realizacji, sama sylwetka Papieża i różne zewnętrzne okoliczności są zbieżne z założeniami Teatru Rapsodycznego, nie można się tu dopatrzeć żadnych sprzeczności. Podobieństwa te pozwalają nazwać Papieża rapsodykiem, a jego styl głoszenia - rapsodycznym. W tym miejscu możemy się jeszcze zastanowić, czy styl ten może być pewną propozycją dla współczesnych głosicieli słowa Bożego. Biorąc pod uwagę fakt, jak wielkie wrażenie wywarła ta homilia na odbiorcach, o czym mówią liczne świadectwa, uwzględniając moc jej oddziaływania nawet obecnie, po 40 latach, styl taki powinien znaleźć licznych naśladowców. Naśladowców rzeczywiście znajduje, wielu kaznodziejów - mniej czy bardziej świadomie - próbuje imitować sposób przepowiadania Jana Pawła II, ale na ogół bez sukcesu. Po pierwsze - bez charyzmy Jana Pawła II ten styl może być odczytany jako sztuczny, a po drugie - we współczesnych realiach styl rapsodyczny na

${ }^{10}$ Warto zwrócić uwagę na wygląd ołtarza. Z dużym prawdopodobieństwem Jan Paweł II nie miał wpływu na to, że organizatorzy zdecydowali się na bardzo minimalistyczną, a jednocześnie wyrazistą dekorację. Olbrzymi krzyż ze stułą z obrazem Matki Bożej był głównym i zarazem jedynym jej elementem. Wydaje się, że sam Kotlarczyk tak właśnie wyobrażałby sobie scenografię do tego papieskiego wystąpienia. 
ambonie raczej nie jest już pożądany. Nie ma szkół i nauczycieli, którzy uczyliby, jak umiejętnie się nim posługiwać. Ponadto zmieniły się czasy, potrzeby, język religijny się przeobraża. Dzisiaj na ambonie dużo bardziej ceni się ekspresję wyrażającą się również w gestach i mimice, spontaniczność, a nawet potoczność. Dowodem na to może być analiza trzech homilii współczesnych popularnych kaznodziejów: abp. Grzegorza Rysia, o. Adama Szustaka i ks. Piotra Pawlukiewicza (Jankosz, Przyczyna, w druku). O żadnym z nich nie można powiedzieć, żeby był rapsodykiem na ambonie. Ta refleksja może być punktem wyjścia w dalszych poszukiwaniach nad najbardziej atrakcyjnym, skutecznym, a jednocześnie odpowiednim stylem we współczesnej homiletyce.

Danuta Michałowska, aktorka, koleżanka Jana Pawła II z młodości, przytacza pewną historię z czasów, gdy był już kardynałem:

$\mathrm{Na}[\ldots]$ aktorskim opłatku [...] zwrócił się do mnie ze słowami: „No to prowadzisz jednoosobowy teatr”. Odpowiedziałam: „Właściwie oboje robimy to samo”. Na to Kardynał - ku mojemu zdziwieniu - żachnął się: „O nie! Ja nie mam nic wspólnego z aktorstwem!”. „Mam na myśli, że oboje na swój sposób służymy Słowu, tak jak w początkach Teatru Rapsodycznego" - odpowiedziałam. „Na to mogę się zgodzić” - stwierdził Kardynał po krótkiej chwili namysłu. (Michałowska 92)

Jan Paweł II unikał nazywania siebie aktorem, bo był przede wszystkim kapłanem i kaznodzieją. Warto jednak zauważyć, że w homiletyce kaznodzieję również określa się mianem sługi słowa Bożego. Co więcej, jest on również sługą Słowa Wcielonego, czyli samego Chrystusa. Na takie określenie - sługa Słowa - Papież się godził. Można więc uznać, że był rapsodykiem nie tylko dlatego, że doskonale opanował warsztat Teatru Rapsodycznego i potrafił wykorzystywać nabyte tam umiejętności, ale przede wszystkim dzięki temu, że za pomocą tego warsztatu służył Słowu, eksponował jego znaczenie i pomagał je zrozumieć innym.

\section{BIBLIOGRAFIA}

Dziedzic, Stanisław. „Adept sztuki teatralnej”. Jan Pawet II człowiek kultury, red. Katarzyna Flader i Witold Kawecki, Dom Wydawniczy Rafael, 2008, ss. 71-90.

Flader-Rzeszowska, Katarzyna. „Sztuka żywego słowa”, encyklopediateatru.pl/hasla/152/sztuka-zywego-slowa. Dostęp 01.05.2019.

Jan Paweł II. Pielgrzymki do ojczyzny. Przemówienia, homilie. Znak, 2010. 
Jankosz, Magdalena. „Rola gestów narracyjnych w publicznych wystąpieniach Jana Pawła II na podstawie wybranych przemówień podczas I pielgrzymki do Polski”. Horyzonty Wychowania, nr 45, 2019, ss.121-131.

Jankosz, Magdalena, ,Sytuacje komunikacyjne publicznych wystąpień Jana Pawła II podczas I pielgrzymki do Polski”. Polonia Sacra, nr 50, 2018, ss. 183-194.

Jankosz, Magdalena, Wiesław Przyczyna. „Forma, język i styl homilii ojca Adama Szustaka, księdza Piotra Pawlukiewicza i arcybiskupa Grzegorza Rysia". Stylistyka [w druku].

Kosiński, Dariusz. „Performer. Jan Paweł II i polski teatr przemiany”. Więź, nr 10, 2008, labo-old.wiez. pl/teksty-korepetycje.php?_performer_jan_pawel_ii_i_polski_teatr_przemiany. Dostęp 01.05.2019.

Kotlarczyk, Mieczysław. Sztuka żywego słowa. Fundacja Teatru Religijnego i Przyjaciół Teatru Rapsodycznego, 1975.

Michałowska, Danuta. „Aktor”. Jan Pawet II człowiek kultury, red. Katarzyna Flader i Witold Kawecki, Dom Wydawniczy Rafael, 2008, ss. 91-100.

Oszajca, Wacław. „Monodram liturgiczny”. Twórczość Karola Wojtyly, red. Zbigniew W. Solski, Wydawnictwo Uniwersytetu Wrocławskiego, 1998, s. 27-39.

Popiel, Jacek. Los artysty w czasach zniewolenia. Wydawnictwo Uniwersytetu Jagiellońskiego, 2006.

Popiel, Jacek. „Krytyk teatralny”. Jan Pawet II człowiek kultury, red. Katarzyna Flader i Witold Kawecki, Dom Wydawniczy Rafael, 2008, ss. 121-143.

Przyczyna, Wiesław. „Kazanie jako słowo Boże”. Fenomen kazania, red. Wiesław Przyczyna. Poligrafia Inspektoratu Towarzystwa Salezjańskiego, 1994, ss. 48-66.

Przyczyna, Wiesław, i Aneta Załazińska. „Paralingwistyczne aspekty oficjalnych wypowiedzi księży”. Mówi się, czyli o mowie i wymowności Polaków, red. Ewa Kołodziejek i Agnieszka Choduń, Materiały IX Forum Kultury Słowa, Volumina.pl, 2016, ss. 127-137.

Sobór Watykański II. Sobór Watykański II. Konstytucje, dekrety, deklaracje. Pallottinum, 1967.

Sokół, Lech. „Orator”. Jan Paweł II człowiek kultury, red. Katarzyna Flader i Witold Kawecki, Dom Wydawniczy Rafael, 2008, ss. 163-180.

\section{RAPSODYK NA AMBONIE?}

JAN PAWEŁ II NA PLACU ZWYCIĘSTWA W WARSZAWIE W ŚWIETLE ZAŁOŻEŃ TEATRU RAPSODYCZNEGO MIECZYSŁAWA KOTLARCZYKA

Streszczenie

Przedmiotem artykułu jest wystąpienie Jana Pawła II na placu Zwycięstwa w Warszawie 2 czerwca 1979 roku podczas I pielgrzymki do Polski. Problem badawczy mieści się w pytaniu, czy Papież, wygłaszając swoją homilię, korzystał z doświadczeń oraz umiejętności wyniesionych z Teatru Rapsodycznego Mieczysława Kotlarczyka i czy był rapsodykiem. W pierwszej części tekstu opisujemy założenia ideowe Teatru Rapsodycznego, w drugiej prezentujemy sposób wygłoszenia homilii przez Jana Pawła II, w trzeciej zaś pokazujemy, które elementy papieskiego wystąpienia są zbieżne z programem artystycznym Kotlarczyka. Odnalezienie tych podobieństw pozwala stwierdzić, że Jan Paweł II był rapsodykiem, czyli sługą słowa.

Słowa kluczowe: Jan Paweł II; homilia na placu Zwycięstwa; Mieczysław Kotlarczyk; rapsodyk, Teatr Rapsodyczny 
A RHAPSODIAN AT THE PULPIT?

JOHN PAUL II AT VICTORY SQUARE IN WARSAW AND THE PREMISES OF MIECZYSŁAW KOTLARCZYK'S RHAPSODY THEATRE

Sum mary

This article discusses John Paul II's speech at Victory Square in Warsaw on 2 June 1979, during the Pope's first pilgrimage to Poland. The subject of the research is the question of whether the Pope, when presenting his homily, used his experience and skills gained in Mieczysław Kotlarczyk's Rhapsody Theatre and whether he was a rhapsodian himself. The first part of the article describes the Rhapsody Theatre's ideological assumptions, while the second presents the way the homily by Pope John Paul II was delivered, and, finally, the third part shows which parts of the papal speech coincided with Kotlarczyk's artistic programme. Finding these similarities allows us to say that John Paul II was indeed a rhapsodian, i.e. a minister of the word.

Keywords: John Paul II; homily in Victory Square; Mieczysław Kotlarczyk; rhapsodian; Rhapsodic Theatre 